entire precipitation, equaled one and one-fourth inches. The cadmium was washed with hot water and then carefully dried. The filtrates were examined but did not reveal a trace of unprecipitated metal. This is a direct contradiction of Heidenreich's statement that " die letzten Reste von Kadmium sind nicht zu entfernen."

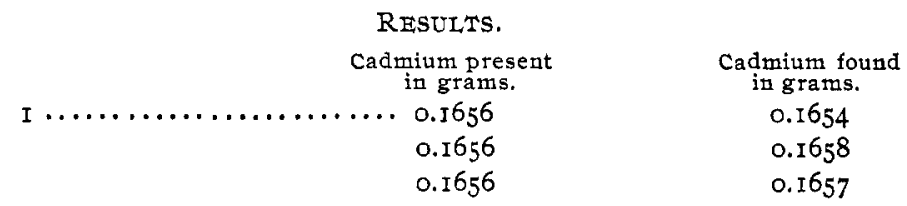

UNIVERSITY OF PENNSYLVANIA.

\title{
PRELIMINARY REPORT OF THE COMMITTEE ON COAL ANALYSIS.
}

To the President and Members of the American Chemical Society :

At the Cleveland meeting of the American Chemical Society a Committee, consisting of W. F. Hillebrand, C. B. Dudley and W. A. Noyes, was appointed to consider the methods of proximate analysis of coal with a view to the adoption, if possible, of uniform methods for this country. After discussion among themselves, the committee have formulated the following outline of methods for analysis which they herewith submit, rather as a means of securing further information than as a final report. The committee very earnestly request all chemists interested in the matter, who may see this report, to send to the chairman of the committee a criticism of the methods proposed and a statement of any objections they see, and of any modifications which they think desirable.

Since the literature of the subject is widely scattered and much of it is not easily accessible, the committee request that all who have published papers bearing on the subject will, if possible, send to the committee reprints of such papers, or, if that cannot be done, a statement of where such papers can be found and the points covered.

Without the full and hearty cooperation of others the labors of the committee will be greatly increased and the conclusions finally arrived at will be less representative of general experience than it is desired they should be. 


\section{METHODS OF ANALYSIS.}

I. Sampling: At least five pounds of coal should be taken for the original sample, with care to secure pieces that represent the average. These should be broken up and quartered down to obtain the smaller sample which is to be reduced to a fine powder for analysis. The quartering and grinding should be carried out as rapidly as possible, and immediately after the original sample is taken, to prevent gain or loss of moisture. The powdered coal should be kept in a tightly stoppered tube or bottle till analyzed.

2. Moisture: Dry one gram of the coal in an open porcelain or platinum crucible at $104^{\circ}-107^{\circ}$ for one hour, best in a doublewalled bath containing pure toluene. Cool in a desiccator and weigh covered.

Question: Has any one experience with other methods of drying ? over sulphuric acid, in vacuo, in a current of air, in watchglasses, or otherwise? Especially in this and other cases, the committee desire any comparative results which can be furnished.

The following comparison of the effect of drying one hour in a toluene bath, twenty hours in vacuo over sulphuric acid, and in air over sulphuric acid was made by Dr. Hillebrand.

\begin{tabular}{|c|c|c|c|c|c|}
\hline \multirow{2}{*}{\multicolumn{2}{|c|}{ Coal No. I ....... }} & \multirow{2}{*}{$\begin{array}{c}20 \text { bours } \\
\text { in vacuo } \\
\text { over } \mathrm{H}_{2} \mathrm{SO}_{4} \\
3.60\end{array}$} & \multicolumn{3}{|c|}{$\begin{array}{l}\text { In air over } \mathrm{H}_{2} \mathrm{SO}_{4} . \\
2 \mathrm{hrs} . \\
28 \mathrm{hrs} . \\
20 \mathrm{hrs}\end{array}$} \\
\hline & & & 2.87 & 3.15 & 3.39 \\
\hline " & $\ldots \ldots \ldots \ldots 3.10$ & 3.59 & $\cdots$ & $\cdots$ & $\cdots$ \\
\hline "، & $\ldots \ldots \ldots \ldots 3.23$ & 3.57 & $\cdots$ & $\cdots$ & $\cdots$ \\
\hline “" & $\ldots \ldots \ldots \ldots 3.25$ & 3.49 & $\cdots$ & $\cdots$ & $\cdots$ \\
\hline “" & $\ldots \ldots \ldots \ldots 3.24$ & $\cdots$ & $\cdots$ & $\cdots$ & $\cdots$ \\
\hline “ & $\ldots \ldots \ldots \ldots 3.22$ & $\cdots$ & $\cdots$ & $\cdots$ & $\cdots$ \\
\hline “ & $\ldots \ldots \ldots \ldots 3.27$ & $\cdots$ & $\cdots$ & $\ldots$ & $\cdots$ \\
\hline Coal No. & $2 \ldots \ldots \ldots \ldots I .84$ & 2.08 & 1.77 & $\cdots$ & 2.00 \\
\hline$"$ & .. $\quad$ I. 83 & 2.07 & $\ldots$ & $\cdots$ & $\cdots$ \\
\hline Coal No. & $3 \ldots \ldots \ldots \ldots$ I.52 & 1.75 & $\mathrm{I} .42$ & $\cdots$ & 1.70 \\
\hline$" “$ & $\ldots \ldots \ldots \ldots$ I.5I & \pm .73 & $\cdots$ & $\ldots$ & .. \\
\hline Coal No. & $4 \ldots \ldots \cdots$ I.OI & 1.04 & 1.05 & $\cdots$ & I.I8 \\
\hline “" & $\ldots \ldots \ldots 1.08$ & 1.03 & $\cdots$ & $\cdots$ & $\cdots$ \\
\hline Coal No. & $5 \ldots \ldots \ldots \ldots$ I.40 & 1.69 & 1.45 & $\ldots$ & 1.66 \\
\hline " & $\ldots \ldots \ldots \ldots r .4 \mathrm{I}$ & 1.67 & $\cdots$ & $\cdots$ & . \\
\hline " & $\ldots \ldots \ldots \ldots, \quad \cdots$ & 1.67 & $\cdots$ & $\cdots$ & $\cdots$ \\
\hline Coal No. & $6 \ldots \ldots \ldots, 0.30$ & $0.2 \mathrm{I}$ & 0.23 & $\cdots$ & 0.25 \\
\hline “ & $\ldots \ldots \ldots, 0.34$ & 0.28 & $\cdots \cdot$ & $\cdots$ & $\cdots$ \\
\hline
\end{tabular}


These results seem to indicate that drying in vacuo gives higher and, probably, more correct results than drying at $105^{\circ}$ for one hour.

The following experiments were carried out by Mr. W. E. Burk at the Rose Polytechnic Institute ${ }^{1}$ for the purpose of determining whether volatile matter other than water is lost in drying bituminous coals. A hard glass tube was partly filled with copper oxide, partly jacketed with a glass sleeve so that a portion could be heated to $100^{\circ}$ by a current of steam. The coal was weighed in an aluminum boat enclosed in a weighing tube, and was then heated to $100^{\circ}$ for an hour in a current of dry air. The moisture and any volatile matters which were expelled were passed over the heated copper oxide and the water and carbon dioxide were absorbed as usual in calcium chloride and in potash bulbs. The results were as follows:

\begin{tabular}{|c|c|c|c|c|c|}
\hline $\begin{array}{l}\text { Weight of } \\
\text { coal taken. }\end{array}$ & $\begin{array}{c}\text { Loss in } \\
\text { weight of } \\
\text { coal at } 100^{\circ} \text {. }\end{array}$ & $\begin{array}{l}\text { Water found } \\
\text { in calcium } \\
\text { chloride tube. }\end{array}$ & $\begin{array}{c}\text { Per cent. of } \\
\text { water in } \\
\text { coal. }\end{array}$ & $\begin{array}{l}\text { Pet cent. of } \\
\text { carbon found } \\
\text { in potash } \\
\text { billbs. }\end{array}$ & $\begin{array}{l}\text { Per cent. of } \\
\text { excess of hy- } \\
\text { drogen } \\
\text { found. }\end{array}$ \\
\hline I. $42 \mathrm{I} 7$ & 0.1994 & 0.2014 & 14.00 & 0.048 & 0.016 \\
\hline I.II95 & 0.1596 & o. I625 & I 4.25 & $0.05^{8}$ & 0.029 \\
\hline 3.1079 & $0.2 \mathrm{III}$ & $0.2 I I 3$ & 6.78 & 0.022 & 0.001 \\
\hline 3.2356 & $0.215^{2}$ & 0.2142 & 6.65 & 0.025 & $\cdots \cdot$ \\
\hline 2.9408 & 0.1967 & 0.19б7 & 6.65 & 0.037 & ..... \\
\hline
\end{tabular}

The amount of moisture found was slightly higher than was found in the same coal by the ustral method, perhaps because of the current of dry air over the coal. Since the loss of volatile matter other than water was always less then one-tenth per cent., it can safely be disregarded for most practical purposes, with coals of this class.

3. Volatile Combustible Matter.-Place one gram of fresh undried coal in a platinum crucible, weighing twenty to thirty grams and having a tightly fitting cover. Heat over the full flame of a Bunsen burner for seven minutes. The crucible should be supported on a platinum triangle with the bottom six to eight $\mathrm{cm}$. above the top of the burner. The flame used should be twenty to twenty-five $\mathrm{cm}$. high when burning free, and the determination made in a place free from draughts. The upper surface of the cover should burn clear, but the under surface should remain covered with carbon. To find "Volatile Com-

1 See Proceedings of the Indiana Academy of Sciences for I8g6, p. II3. 
bustible Matter," subtract the per cent. of moisture from the loss found here.

Questions: Should a larger portion be taken? Should the coal be heated more gradually at first? Should a blast be used ? Can results be obtained by heating in a muffle, or in any other manner, which will agree with those obtained by this method?

The committee consider the determination as largely arbitrary, in any case, and believe that uniform results in the hands of different chemists will be best secured by making the conditions as simple as possible. The most serious objection to the method proposed appears to be the danger of mechanical loss at the commencement of the heating. It is believed, however, that the error from this source is less than would arise from any method which leaves the application of the heat to the judgment of the operator.

The committee especially desire to secure any analytical data which may be available to show the degree of concordance of results obtained by the same or different chemists. Also any comparison of analytical results with results of commercial coking.

4. Ash.-Burn the portion of coal used for the determination of moisture, at first over a very low flame, with the crucible open and inclined, till free from carbon. If properly treated, this sample can be burned much more quickly than the dense carbon left from the determination of volatile matter.

Question: Are carbonates likely to be present in the ash in such amount that heating over a blast would lessen the weight appreciably?

When the sulphur in the coal is in the form of pyrites, that compound is converted almost entirely into ferric oxide in the determination of the ash and, since three atoms of oxygen replace four atoms of sulphur the weight of the ash is less than the weight of the mineral matter in the coal by five-eighths of the weight of the sulphur. While the error from this source is sometimes considerable, the committee is not now prepared to recommend such a correction.

5. Fixed Carbon. - This is found by subtracting the per cent. of ash from the per cent. of coke as found in paragraph 3 . 
6. Sulphur.-What methods are used? Eschka's, with sodium or potassium carbonate, fusion with sodium carbonate and potassium nitrate, Carius' or others? Any comparative results are especially desired.

7. The committee would recommend that the heating effect be calculated on the basis of the coal burned to carbon dioxide and vapor of water at $100^{\circ} \mathrm{C}$., and be stated either in calories per kilogram or English heat units per pound. The theoretical evaporative effect is to be calculated by dividing the number of calories per kilogram by 536 or the number of English heat units per pound by 965 . In either case it expresses the theoretical number of kilograms or pounds of water converted into steam from and at $100^{\circ} \mathrm{C}$. by one kilogram or pound of the coal.

A calculation of the results of twenty-one analyses, and determinations of heating effect with the bomb calorimeter, made with Indiana and Pittsburg bituminous coals, shows that the heating effect may be found in all cases examined, with a maximum error of two per cent., by the following rule:

Subtract from Ioo the per cents. of moisture and ash and onehalf the per cent. of sulphur, and multiply the remainder by 80.7. The product will be the heating effect of the coal burned to vapor of water, expressed in calories.

The committee will be glad of any data which will enable them to further test this factor and also of any data with regard to other methods of determining heating effect.

Persons interested in the subject of coal analysis are requested to send any communications which they may wish to make, to Prof. W. A. Noyes, Rose Polytechnic Institute, Terre Haute, Ind.

W. A. NOYEs,

C. B. DUDLEY,

W. F. HILLEBRAND,

Februaty 22, 1898 .

Committee. 